\title{
Prevalence of bacterial vaginosis and associated factors among pregnant women attending at Bugando Medical Centre, Mwanza, Tanzania
}

\author{
PROSPER A. SHAYO ${ }^{1}$, ALBERT KIHUNRWA ${ }^{1}$, ANTHONY N. MASSINDE ${ }^{1 *}$, MIRIAM MIRAMBO ${ }^{2}$, \\ RICHARD RUMANYIKA ${ }^{1}$, NNHANDI NGWALIDA ${ }^{1}$, BALTHAZAR GUMODOKA ${ }^{1}$, JEREMIAH \\ KIDOLA $^{3}$ and MOKE MAGOMA ${ }^{1}$ \\ ${ }^{1}$ Department of Obstetrics and Gynaecology, Bugando Medical Centre, P.O. Box 1370, Mwanza, Tanzania \\ ${ }^{2}$ Department of Microbiology, Catholic University of Health and Allied Sciences, Box 1464, Mwanza, Tanzania \\ ${ }^{3}$ National Institute for Medical Research, Mwanza Research Centre, P.O. Box 1462, Mwanza, Tanzania
}

\begin{abstract}
Bacterial vaginosis (BV) is an extremely common reproductive tract condition worldwide with reported high prevalence among African population. Factors associated with this condition include preterm labour, premature rupture of membranes, preterm delivery and possibly spontaneous abortion. Nevertheless, antenatal screening and treatment is not routinely available in most poor-resource countries including Tanzania. A cross-sectional descriptive study was conducted among delivering women at Bugando Medical Centre (BMC), Mwanza, Tanzania to determine the magnitude of the BV using the Nugent's criteria and to document factors associated with the condition. A total of 284 women who presented for delivery at BMC labour ward from February to March 2011 were recruited into the study. For each consented women, a vaginal swab was taken, samples collected tested and a Nugent's score of at least seven indicated bacterial vaginosis. Overall, bacterial vaginosis was diagnosed in $28.5 \%(\mathrm{n}=81)$ of all participants. Gardnerella was the commonest morphotypes found in approximately $66.2 \%(\mathrm{n}=188)$ of all participants while $11.6 \%$ (33 participants) had Mobilincus. There were no evidence for the association between bacterial vaginosis having formal education, (OR, 1.42[95\% CI, 0.29-6.97; $\mathrm{p}=0.667])$. Urban residence (OR, 1.29 [95\% CI, 0.76-2.19; $\mathrm{p}=0.352]$ ), ever delivered before (OR $0.66[95 \% \mathrm{CI}, 0.39-1.12 ; \mathrm{p}=0.126])$, vaginal practice to enhance dry sex (OR, 1.16[95\%CI, 0.43-3.17; $\mathrm{p}=0.768$ ]) or wet sex (OR 1.31[95\%CI, 0.46-3.7; $\mathrm{p}=0.613]$ ), gestation age less than 37 weeks (OR 0.82[95\% CI, 0.45-1.51; $\mathrm{p}=0.534$ ]) and HIV infection (OR 0.90[95\% CI, 0.28-2.92; $\mathrm{p}=0.863]$ ) were not associated with bacterial vaginosis. Bacterial vaginosis is common among women delivering at Bugando Medical Centre and more studies to include antenatal clinic attendees initiating care are required to reliably document the magnitude the condition.
\end{abstract}

Keywords: bacterial vaginosis, Nugent score, pregnancy, Tanzania

\section{Introduction}

Bacterial vaginosis (BV) is among the most common reproductive tract condition worldwide characterised by low levels of lactobacilli and an increased frequency of facultative anaerobic bacteria. Its prevalence among African population has been estimated to range from $20 \%$ to $50 \%$, and even higher levels have been documented among female sex workers (Fleury, 1981; Cristiano et al., 1989; Ramjee et al., 1998; McGregory, 2000; Holzman et al., 2001; Fonck et al., 2001; Riedner et al., 2003; Myer et al., 2005). Although the aetiology of BV is still unknown, the condition is associated with changes in vaginal ecology, resulting into overgrowth of certain bacteria such as Gardnerella vaginalis, Mycoplasma homonis, Ureaplasma urealyticum, Mobiluncus spp., Provotella spp., Bacteroides spp. and the depletion of hydrogen producing lactobacilli (Hill, 1993) (Hill 1993). Other factors known to increase the risk of BV include sexual activities, vaginal hygiene practices, HIV infection, marital status, black race and sexually transmitted infections including Herpes simplex type 2 (Goldenbert et al., 1996; Ness et al., 2002; Bukusi et al., 2006; Hassan et al., 2007; Fethers et al., 2008, 2012; Chepes et al., 2008; Haggerty et al., 2009).

*Correspondence: Anthony Massinde; E-mail: amassinde@yahoo.com 
Among pregnant women, BV is associated with adverse perinatal and pregnancy outcomes such as increased risk of preterm labour, premature rupture of membranes, preterm delivery, chorioamnionitis and possibly, spontaneous abortion (Hillier et al., 1988, 1995; Krohn et al., 1993; Usui et al., 2002; Leitich et al., 2003). In addition, BV has also been associated with an increased risk of acquiring human immunodeficiency virus (HIV) infection (Cohen et al., 1995; Sewankambo et al., 1997; Taha et al., 1998; Schellenberg et al., 2012). Similar evidence from Tanzania is scarce, although studies among other population groups such as bar and hotel workers in the country suggest high prevalence (Kapiga et al. 2005).

Most women with BV may be asymptomatic (Amsel et al. 1983), thus early detection, especially among pregnant women is essential for timely treatment to prevent related complication(s). Antenatal BV screening is not a routine practice at Bugando Medical Centre and no study on BV has ever been conducted at the hospital. This cross-sectional analytical study was conducted to determine the magnitude and factors associated with BV among women delivering at Bugando Medical Centre in Mwanza, Tanzania.

\section{Materials and Methods}

\section{Study design}

This analytical cross-sectional survey was carried out at Bugando Medical Centre (BMC) labour ward among women reporting in labour. Bugando Medical Centre is a 850-bed referral and teaching hospital located in Mwanza, north-western Tanzania. Approximately 600 women deliver in the facility every month (www.bugandomedicalcentre.go.tz).

\section{Study subjects and sample size}

Study subjects were pregnant women who consented to participate in the study. Women were excluded if they declined to participate, had already ruptured membranes, were diagnosed of antepartum haemorrhage, carcinoma of the cervix and if for some reason(s) she was unable to consent despite the eligibility. Women in the last group included those with altered mental status or severe illness. For participants aged less than 18 years, consent was requested from accompanying adults and where such adults were unavailable, women were excluded.

The sample size for the study was 284 women, and was calculated using a formula by (Cochran, 1963) based on the prevalence of BV among pregnant women of $24.4 \%$ reported in Zimbabwe (Tolosa et al., 2006).

\section{Data collection}

Data was collected from mid February to mid March 2011. Data were collected from all participants using a pre-tested structured questionnaire that included demographic, gynaecological, medical and obstetric characteristics. The demographic data were age, occupation, level of education, marital status and household possessions. The household possessions were used to calculate the woman's wealth quintile. The obstetric history included information on the rank of the present pregnancy (gravidity), the number of deliveries the participant had ever had (parity-delivery of a live or dead foetus from a pregnancy of at least seven months gestation), any previous pregnancy loss including perinatal death. The gynaecological characteristics collected were history of gynaecological infections in the past and age at first menstruation (menarche). History of any chronic 
medical conditions such as diabetes mellitus, HIV infection or AIDS, hypertension and sickle cell anaemia were also collected. HIV serostatus for all women were documented from available records on the antenatal cards women carry along when they report to labour ward. This is part of the routine antenatal investigation done to almost all pregnant women countrywide. HIV testing was offered to all women with unknown status.

\section{Vaginal sample collection and laboratory procedures}

Each participant was instructed to assume a lithotomy position and a sterile unlubricated speculum inserted into the vagina and a sterile cotton swab used to swab the vagina walls (lateral, anterior and posterior fornices) before it was streaked on a sterile examination glass to obtain a vaginal smear. The smear was then heat fixed by passing through a flame at least 3 times and a sticker with a unique identification number applied. The number of the specimen was also recorded into the results template.

The slide was gram stained and evaluated microscopically at a high magnification (x1500) based on the Nugent score (Nugent et al., 1991). A score of 0 to 10 was assigned on the basis of the relative proportions of easily distinguished bacterial morphological types. The morphotypes were large gram-positive rods (Lactobacillus species), small gram-negative or gram-variable rods (Bacteroides or Gardnerella species), and curved gram-negative to gramvariable rods (Mobiluncus species). A score of 0-3 was categorized as normal, 4-6 intermediate and 7-10 was considered diagnostic of BV. A score of 0 was assigned to the most lactobacillus predominant vaginal flora and a score of 10 was assigned to those in which lactobacilli floras were largely replaced by Gardnerella, Bacteroides and Mobiluncus. Two experienced microscopists were used to score the vagina smear and in case of a discrepancy, a third opinion was sought and her/his opinion was final. Furthermore, five randomly selected slides were scored by an independent microscopist against a collection of smears pre-scored. In all, there was $90 \%$ concordance, indicating that scoring was comparable and consistent.

\section{Data analysis}

Collected data were reviewed daily for completeness and consistence of the responses. Data were doubly entered to ensure that entered data quality did not rely on a single person. Where discrepancies were found, the two data entry clerks were summoned together with the questionnaire to identify and rectify the difference.

Collected data were double entered into SPSS statistical database. Consistent, validity checks and cleaning were done using the same package. Data were later imported into STATA statistical package in Windows version 11 (StataCorp LP College Station, Texas, USA 2005) for analysis. Frequency distribution and proportions were used to describe participants' baseline characteristics as well as factors associated with BV. In calculating the wealth quintile, the household possessions that an individual had: type of house (walls, roof and floor), source of drinking water, source of power for cooking for the household, source of power for lighting, whether the family had a radio, bicycle, refrigerator or television and the type of toilet the family used were entered in a principal component analysis model in STATA and the Kaiser-Mayer-Olkin (KMO) measure of sampling adequacy applied. Household possessions with a KMO of less than $60 \%$ were excluded in a later model which was used to calculate the wealth index. Having a bicycle, a motorcycle and the type of roofing of the house had less $\mathrm{KMO}$ and thus were excluded in the final model. 
Subsequently, the index was divided into quintiles: the lowest, the second, the third, the fourth and the highest in order of the wealth the individual household had.

For numerical data mean \pm standard deviation was calculated at $95 \%$ confidence level. Scores 0-3 and 4-6 were grouped and categorized as 0 and category 7-10 as 1 to denote absence and presence of BV respectively and entered in the binary logistic regression model to determine the association of various factors and BV. The association is reported as odds ratio together with the $95 \%$ confidence intervals and respective p-values.

\section{Ethical consideration}

Ethical clearance was sought and obtained from Bugando University College of Health Sciences /Bugando Medical Centre Research Ethics Committee. Written informed consent was requested and obtained from all participants. For literate women, the consent information was provided followed by a consent form which each participant was required to sign to signify her consent while the consent information sheet was read in its entirety to non-literate participants. The later were also required to thumb print on the consent form to signify their informed consent to participate in the study. Explanation was made that participation was voluntary and those declining to participate were still entitled to the standard care provided to all women in the labour ward. All filled questionnaires were examined for completeness daily by the principal investigator and stored securely in a locker. Data entries were done on the following day. For each participant, only a study unique participant identification number was recorded on the laboratory forms and questionnaire. All filled questionnaires were destroyed after the data entry and cleaning.

\section{Results}

Of the total 626 pregnant women who attended the hospital for delivery 284 were recruited into the study. The median age of the participants was 26 years. The majority $87.7 \%(\mathrm{~N}=249)$ were married, and just over $12.3 \%$ were single or separated. Generally, most participants $(65.8 \%)$ had primary school education. Over half $(53.5 \%)$ of all participants were housewives. Of the 187 participants who had ever delivered, the median number of parity was two. Slightly over half $(58.8 \% ; \mathrm{N}=167)$ of the study participants were from rural areas. Participants were also almost evenly distributed in the wealth quintiles (Table 1).

Bacterial vaginosis (Nugent score 7-10) was found in 28.5\% and Gardenella was the commonest morphotype accounting for approximately $66.2 \%$ of all BV cases followed by Mobilincus (11.6\%). 
Table 1: Baseline social demographic characteristics of study participants

\begin{tabular}{lll}
\hline Characteristics & Responses & Number (\%) \\
Education & None & $9(3.2)$ \\
& Primary & $187(65.8)$ \\
& Secondary & $74(26.1)$ \\
Marital status & Post Secondary & $14(4.9)$ \\
& Single & $319(10.9)$ \\
Occupation & Married & $249(87.7)$ \\
& Separated & $4(1.4)$ \\
Residence & Housewife & $152(53.5)$ \\
& Petty trader & $61(4.5)$ \\
Wealth quintile & Employed & $38(13.4)$ \\
& Urban & $117(41.2)$ \\
& Rural & $167(58.8)$ \\
& Lowermost & $56(19.7)$ \\
& $2^{\text {nd }}$ & $57(20.1)$ \\
& $3^{\text {rd }}$ & $54(19.0)$ \\
Total & $4^{\text {th }}$ & $59(20.8)$ \\
& Highest & $58(20.4)$ \\
\hline
\end{tabular}

Table 2 shows the association between BV and various predetermined factors in a binary logistic regression model. There was no evidence to suggest association between bacterial vaginosis and practices of inserting materials into the vagina to enhance dry or wet sex (OR 1.20CI 0.43-3.17 and 0.80 CI 0.37-1.77, respectively) and HIV (OR 0.90 CI 0.28-2.92). Bacterial vaginosis was also not associated with factors such as level of education (at least primary education and less or none), residence (urban, semi-urban or rural) and marital status.

Table 2: Predictors of bacteria vaginosis among 284 pregnant women who delivered at BMC

\begin{tabular}{|c|c|c|c|c|}
\hline Variable & Response & $\begin{array}{l}\text { Bacterial vaginosis } \\
\text { absent N (\%) }\end{array}$ & $\begin{array}{l}\text { Bacterial vaginosis } \\
\text { present N (\%) }\end{array}$ & $\begin{array}{l}\text { Crude (OR and } 95 \% \\
\text { CI interval) }\end{array}$ \\
\hline \multirow[t]{2}{*}{ Gestational age } & $<=37$ & $29(30.2)$ & $67(69.8)$ & $0.88(0.52-1.53)$ \\
\hline & $>=37$ & $52(27.8)$ & $135(72.2)$ & 1.00 \\
\hline \multirow[t]{2}{*}{ Education } & No education & $2(22.2)$ & $7(77.2)$ & 1 \\
\hline & Educated & $79(28.8)$ & $195(71.2)$ & $1.42(0.29-6.97)$ \\
\hline \multirow[t]{2}{*}{ Marital status } & Not married & $10(28.6)$ & $25(71.4)$ & 1 \\
\hline & Married & $71(28.6)$ & $177(71.4)$ & $1.00(0.46-2.19)$ \\
\hline \multirow[t]{5}{*}{ Occupation } & None & $9(36.0)$ & $16(64.0)$ & 1 \\
\hline & Housewife & $45(29.6)$ & $107(70.4)$ & $0.71(0.31-1.81)$ \\
\hline & Employed & $6(15.8)$ & $36(84.2)$ & $0.33(0.10-1.10)$ \\
\hline & Business & $18(30.0)$ & $18(30.0)$ & $0.76(0.28-2.04)$ \\
\hline & Peasant & $3(42.9)$ & $3(42.9)$ & $1.33(0.24-7.33)$ \\
\hline \multirow[t]{3}{*}{ Residence } & Urban & $30(25.6)$ & $87(74.4)$ & $0.84(0.46-1.55)$ \\
\hline & Semi urban & $27(29.03)$ & $66(71.0)$ & 1 \\
\hline & Rural & $24(32.9)$ & $202(71.4)$ & $1.20(0.61-2.32)$ \\
\hline \multirow[t]{2}{*}{ Wet sex } & No & $76(29.2)$ & $184(70.8)$ & 1.00 \\
\hline & Yes & $5(23.8)$ & $16(76.2)$ & $0.80(0.37-1.77)$ \\
\hline \multirow[t]{2}{*}{ Dry sex } & No & $75(28.4)$ & $189(71.6)$ & 1 \\
\hline & Yes & $6(31.6)$ & $13(68.4)$ & $1.2(0.43-3.17)$ \\
\hline \multirow[t]{2}{*}{ Booking } & Not booked & $25(35.2)$ & $46(64.8)$ & 1 \\
\hline & Booked & $56(26.4)$ & $156(73.6)$ & $0.66(0.37-1.17)$ \\
\hline \multirow[t]{2}{*}{ Candidiasis } & No & $63(30.1)$ & $146(69.9)$ & 1 \\
\hline & Yes & $18(24.3)$ & $56(75.7)$ & $0.74(0.41-1.37)$ \\
\hline
\end{tabular}




\begin{tabular}{|c|c|c|c|c|}
\hline HIV & $\begin{array}{l}\text { No } \\
\text { Yes }\end{array}$ & $\begin{array}{l}77(28.7) \\
4(26.7)\end{array}$ & $\begin{array}{c}191(71.3) \\
11(73.3)\end{array}$ & $\begin{array}{l}1 \\
0.90(0.28-2.92)\end{array}$ \\
\hline
\end{tabular}

\section{Discussion}

The magnitude of bacterial vaginosis found in this study was slightly higher than the one reported 14 years ago by Mayaud et al., (1998). In a recent study in Dar es Salaam, a prevalence of $60.6 \%$ has been reported by Aboud et al. (2008). Levels as high as $83.3 \%$ and $62.9 \%$ have been reported among non-pregnant women in previous studies elsewhere in Tanzania (Tanton et al. 2011; Baisley et al., 2009) and elsewhere in Africa (Pepin et al., 2011). The current study was conducted among women delivering in a tertiary health facility who are usually referred from lower level facilities for various pregnancy-related conditions. Their health care seeking behaviour might have been influenced by ante-natal care (ANC) clinic attendance and some might have received antimicrobial drugs for other conditions with effect on vaginal flora. Nevertheless, similar to previous studies from other settings, Gardenella was the most predominant morphotype (Nelson et al., 2009; Dumonceaux et al., 2009).

In this study bacterial vaginosis was not associated with factors such as practices of inserting materials into the vagina to enhance dry or wet sex and marital status. Studies from elsewhere have highlighted the association between bacterial vaginosis and such conditions (Cohen et al., 1995; Sewankambo et al., 1997; Ness et al., 2002; Bukusi et al., 2006; Hassan et al., 2007; Cherpes et al., 2008; McClelland et al., 2008; Aboud et al., 2008; Haggert et al., 2009; Mitchell et al., 2009). This variation may be explained by the difference in study population - pregnant women were used in the current study while non-pregnant women were used in other studies. Additionally, in the current study details of the practices such as type of materials used, the duration as well as how frequent they were used were not recorded. Therefore, the possible effect(s) of such practices on vaginal flora could not be explained.

Our study found no association between bacterial vaginosis and HIV infection. Previous studies have highlighted a strong association of both symptomatic and asymptomatic bacterial vaginosis and HIV infection as well as possible maternal and foetal morbidity (Hillier et al., 1988; Cohen et al., 1995; Sewankambo et al., 1997; Subtil et al., 2002; Usui et al., 2002; Leitich et al., 2003; Mitchell et al., 2009; Schellenberg et al., 2012). A near universal uptake of prevention of mother to child transmission of HIV services in the study setting meant that women are possibly identified early and initiated on prophylaxis or treatment, thus influencing systemic and local vaginal immunity likely to affect the pattern of vaginal flora.

The major strength of this study is the rigour in arriving at the diagnosis of bacterial vaginosis. However, the limitations of this study need to be highlighted. Notably, the study involved women who sought delivery care at the hospital in a one-month period, and thus may not be representative of the annual population served by the hospital. Additionally, only women delivering at the hospital were included in this study, and therefore the results will not apply to antenatal women seen at the hospital in the same period. Nevertheless, the results suggest a high magnitude of the condition, and a need for a similar study among antenatal women at the ANC clinic to document the magnitude of the problem.

In conclusion, BV is common among women delivering at this facility. A similar study among ANC women in the facility is required to reliably document the magnitude 
and the association of the condition with HIV. Studies to determine the effect of bacterial vaginosis on pregnancy outcomes are also required to provide evidence for (or lack thereof) practice change to include routine bacterial vaginosis screening in the minimum ANC package.

\section{Acknowledgements}

We extend our sincere gratitude to the following people: Mary Louse Shushu, for all the assistance on the laboratory work and all staff of Obstetrics and Gynaecology Department at Bugando Medical Centre for the assistance given during the period of data collection. We would like to thank all pregnant mothers for participating in this study. This study received financial assistance from the Embassy of Belgium through the Belgian Technical Cooperation.

\section{Competing interest}

Authors declare no conflict of interest.

\section{References}

Aboud, S., Msamanga, G., Read, J.S., Mwatha, A., Chen, Y.Q., Potter, D., Valentine, M., Sharma, U., Hoffmann, I., Taha, T.E., Goldenberg, R.L. \& Fawzi, W.W. (2008) Genital tract infections among HIV-infected pregnant women in Malawi, Tanzania and Zambia. International Journal of STD AIDS 19, 824-832.

Amsel, R., Totten, P.A, Spiegel, C.A., Chen, K.C., Eschenbach, D. \& Holmes, K.K. (1983) Non-specific vaginitis: Diagnostic criteria and microbial and epidemiologic associations. American Journal of Medicine 74, 14-22.

Baisley, K., Changalucha, J., Weiss, H.A., Mugeye, K., Everett, D., Hambleton, I., Hay, P., Ross, D., Tanton, C., Chirwa, T., Hayes, R. \& Watson-Jones, D. (2009) Bacterial vaginosis in female facility workers in north-western Tanzania: prevalence and risk factors. Sexually Transmitted Diseases 85, 370-375.

Bukusi, E.A., Cohen, C.R. \& Meier, A.S. (2006) Bacterial vaginosis: risk factors among Kenyan women and their male partners. Sexually Transmitted Diseases 33, 361-367.

Cherpes, T.L., Hillier, S.L., Meyn, L.A., Busch, J.L. \& Krohn, M.A. (2008) A delicate balance: risk factors for acquisitionof bacterial vaginosis include sexual activity, absence of hydrogen peroxide-producing lactobacilli, black race, and positive herpes simplex virus type 2 serology. Sexually Transmitted Diseases 35, 78-83.

Cochran, W.G. (1963) Sampling Techniques. New York: John Wiley and Sons, Inc.

Cohen, C.R., Duerr, A., Pruithithada, N., Rugpao, S., Hillier, S. L., Garcia, P. \& Nelson, K. (1995) Bacterial vaginosis and HIV sereprevalence among female commercial sex workers in Chiang Mai,Thailand. AIDS 9, 1093-1097.

Cristiano, L., Coffetti, N., Dalvai, G., Lorusso, L. \& Lorenzi, M. (1989) Bacterial vaginosis: prevalence in outpatients, association with some micro-organisms and laboratory indices. Genitourinary Medicine 65, 382-387.

Dumonceaux, T.J., Schellenberg, J., Goleski, V., Hill, J.E., Jaoko, W., Kimani, J., Money, D., Ball, T. B.F., Plummer, F.A. \& Severini, A. (2009) Multiplex detection of bacteria associated with normal microbiota and with bacterial vaginosis in vaginal swabs by 
use of oligonucleotide-coupled fluorescent microspheres. Journal of Clinical Microbiology 47, 4067-4077.

Fethers, K., Twin, J., Fairley, C.K., Fowkes, F.J., Garland, S.M., Fehler, G., Morton, A.M., Hocking, J.S., Tabrizi, S.N. \& Bradshaw, C.S. (2012) Bacterial vaginosis (BV) candidate bacteria: associations with BV and behavioural practices in sexuallyexperienced and inexperienced women. PLoS One, 7, e30633.

Fethers, K.A., Fairley, C.K. \& Hocking, J.S. (2008) Sexual risk factors and bacterial vaginosis:a systematic review and meta-analysis Clinical Infectious Disease 47, 14261435.

Fleury, F.S. (1981) Adult Vaginitis. Clinical Obstetrics and Gynaecology, 24, 407-438.

Fonck, K., Kaul, R. \& Keli, F. (2001) Sexually transmitted infections and vaginal douching in a population of female sex workers in Nairobi, Kenya Sexually Transmitted Infections $77,271-275$.

Goldenberg, R.L., Klebanoff, M. A., Nugent, R., Krohn, M.A., Hillier, S. \& Andrews, W. (1996) Bacterial colonization of the vagina during pregnancy in four ethnic groups. American Journal of Obstetrics and Gynecology 174, 1618-1621.

Haggerty, C.L., P. A. Totten, P.A., Ferris, M., Martin, D.H., Hoferka, S. Astete, S.G., Ondondo, R., Norori, J. \& Ness, R.B. (2009) Clinical characteristics of bacterial vaginosis among women testing positive for fastidious bacteria. Sexually Transmitted Infections, 85, 242-248.

Hassan, W.M., Lavreys, L., Chohan, V., Richardson, B.A., Mandaliya, K., Ndinya-Achola, J.O., Kiarie, J., Jaoko, W., Holmes, K.K. \& McClelland, R.S. (2007) Associations between intravaginal practices and bacterial vaginosis in Kenyan female sex workers without symptoms of vaginal infections. Sexually Transmitted Diseases 34, 384.

Hernandez-Rodriguez, C., Romero-Gonzalez, R., Albani-Campanario, M., Figueroa-Damian, R., Meraz-Cruz, N. \& Hernandez-Guerrero, C. (2011) Vaginal microbiota of healthy pregnant Mexican women is constituted by four Lactobacillus species and several vaginosis-associated bacteria. Infectious Diseases in Obstetrics and Gynecology 2011, 851485.

Hill, G.B. (1993) The microbiology of bacterial vaginosis American Journal of Obstetrics and Gynecolology 169, 450-454.

Hillier, S.L., Martius, J., Krohn, M.., Kiviat, N., Holmes, K.K. \& Eschenbach, D.A. (1988) A case-control study of chorioamnionic infection and histologic chorioamnionitis in prematurity. New England Journal of Medicine 319, 972-978.

Hillier, S.L., Nugent, R.P., Eschenbach, D.A., Krohn, M.A., Gibbs, R. \& Martin, D.H. (1995) Association between bacterial vaginosis and preterm delivery of a low-birth-weight infant New England Journal of Medicine 333, 1737-1742.

Holzman, C., Leventhal, J.M. \& Qiu, H. (2001) Factors linked to bacterial vaginosis in nonpregnant women. American Journal of Public Health, 91, 1664-1670.

Kapiga, S.H., Sam, N.E., Masenga, E.J., Manongi, R. \& Shao, J.F. (2005) Risk factors for bacterial vaginosis among bar and hotel workers in Northern Tanzania. East African Medical Journal 82, 85-91.

Krohn, M.A., Hillier, S.L., Kiviat, N.B. \& Eschenbach, D.A. (1993) The severity of fetal membrane infection and pregnancy complications Annals of Epidemiology 3, 78-85.

Leitich, H., Bodner-Adler, B., Brunbauer, M., Kaider, A., Egarter, C. \& Husslein, P. (2003) Bacterial vaginosis as a risk factor for preterm delivery: a metaanalysis. American Journal of Obstetrics and Gynecolology 189, 139-147. 
Marrazzo, J.M., Fiedler, T. L., Srinivasan, S., Thomas, K.K., Liu, C., Ko, D., Xie, H., Saracino, M. \& Fredricks, D.N. (2012) Extravaginal reservoirs of vaginal bacteria as risk factors for incident bacterial vaginosis. Journal of Infectious Diseases, 205, 1580-1588.

Mayaud, P., Uledi, E., Cornelissen, J., ka-Gina, G., Todd, J., Rwakatare, M., West, B., Kopwe, L., Manoko, D., Grosskurth, H., Hayes, R. \& Mabey, D.(1998) Risk scores to detect cervical infections in urban antenatal clinic attenders in Mwanza, Tanzania. Sexually Transmitted Infections 74 Suppl 1:S139-146.

McClelland, R.S., Richardson, B.A., Graham, S.M., Masese, L.N., Gitau, R., Lavreys, L., Mandaliya, K., Jaoko, W., Baeten, J.M. \& Ndinya-Achola, J.O. (2008) A prospective study of risk factors for bacterial vaginosis in HIV-1 seronegative African women. Sexually Transmitted Diseases, 35, 617-623.

McGregory, J.A. (2000) Bacterial vaginosis in pregnancy. Obstetrical \& Gynecological Survey $55,1$.

Mitchell, C., Moreira, C.,Fredricks, D., Paul, K., Caliendo, A..M., Kurpewski, J., Ingersoll, J. \& Cu-Uvin, S. (2009) Detection of fastidious vaginal bacteria in women with HIV infection and bacterial vaginosis. Infectious Diseases in Obstetric and Gynecology 2009, 236919.

Myer, L., Denny, L. \& Telerant, R. (2005) Bacterial vaginosis and susceptibility to HIV infection in South African women: a nested case-control study. Infectious Disease 192, 1372-1380.

Nelson, D.B., Hanlon, A., Hassan, S., Britto, J., Geifman-Holtzman, O., Haggerty, C. \& Fredricks, D.N. (2009) Preterm labor and bacterial vaginosis-associated bacteria among urban women. Journal of Perinatal Medicine, 37, 130-134.

Ness, R.B., Hillier, S.L., Richter, H.E., Soper, D.E., Stamm, C., McGregory, J., Bass, D.C., Sweet, R.L. \& Rice, P. (2002) Douching in relation to bacterial vaginosis, lactobacilli, and facultative bacteria in the vagina. Obstetrics $\mathcal{E}$ Gynecology, 100, 765.

Nugent, R.P., Krohn, M.A. \& Hillier, S.L. (1991) The reliability of diagnosing bacterial vaginosis is improved by a standardized method of gram stain interpretation. Journal of Clinical Microbiology 29, 297-301.

Pepin, J., Deslandes, S., Giroux, G., Sobela, F., Khonde, N., Diakite, S., Demeule, S., Labbe, A.C., Carrier, N. \& Frost, E. (2011) The complex vaginal flora of West African women with bacterial vaginosis. PLoS One, 6, e25082.

Ramjee, G., Karim, S.S. \& Sturm, A.W. (1998) Sexually transmitted infections among sex workers in KwaZulu-Natal, South Africa. Sexually Transmitted Diseases 25, 346-349.

Riedner, G., Rusizoka, M. \& Hoffmann, O. (2003) Baseline survey of sexually transmitted infections in a cohort of female bar workers in Mbeya Region, Tanzania. Sexually Transmitted Infections 79, 382-387.

Schellenberg, J.J., Card, C.M., Ball, T.B., Mungai, J.N., Irungu, E., Kimani, J., Jaoko, W., Wachihi, C., Fowkes, K.R. \& Plummer, F.A. (2012) Bacterial vaginosis, HIV serostatus and T-cell subset distribution in a cohort of East African commercial sex workers: retrospective analysis. AIDS, 26, 387-393.

Sewankambo, N., Gray, R.H., Wawer, M.J., Paxton, L., McNairn, D., Wabwire-Mangen, F., Serwadda, D., Li, C., Kiwanuka, N., Hillier, S.L., Rabe, L., Gaydos, C.A., Quinn, T.C. \& Konde-Lule, J. (1997) HIV-1 infection associated with abnormal vaginal flora morphology and bacterial vaginosis. Lancet, 350, 546-550. 
Subtil, D., Denoit, V., Goueff, F.L., Husson, M.O., Trivier, D. \& Puech, F. (2002) The role of bacterial vaginosis in preterm labour and preterm birth: a case-control study. European Journal of Obstetric, Gynaecology and Reproductive Biology 101, 41-46.

Taha, T.E., Hoover, D.R., Dallabetta, G.A., Kumwenda, N.I., Mtimavalye, L.A.R., Yang, L., Liomba, G.N., Broadhead, R.L., Chiphangwi, J.D. \& Miotti, P.G. (1998) Bacterial vaginosis and disturbances of vaginal flora: association with increased acquisition of HIV. AIDS 12, 1699-1706.

Tanton, C., Weiss, H.A., Le Goff, J., Changalucha, J., Rusizoka, M., Baisley, K., Everett, D., Ross, D.A., Belec, L., Hayes, R.J. \& Watson-Jones, D. (2011) Correlates of HIV-1 genital shedding in Tanzanian women. PLoS One 6, e17480.

Tolosa, J.E., Chaithongwongwatthana, S., Daly, S., Maw, W.W., Gaitan, H., Lumbiganon, P., Festin, M., Chipato, T., Sauvarin, J., Goldenberg, R.L., Andrews, W.W. \& Whitney, C.G. (2006) The International Infections in Pregnancy (IIP) study: Variations in the prevalence of bacterial vaginosis and distribution of morphotypes in vaginal smears among pregnant women. American Journal of Obstetrics and Gynecology, 195, 11981204.

Usui, R., Ohkuchi, A., Matsubara, S., Izumi, A., Watanabe, T., Suzuki, M. \& Minakami, H. (2002) Vaginal lactobacilli and preterm birth. Journal of Perinatal Medicine 30, 458-466. 